\title{
STEWARTSHIP AND EVOLVING FIDELITY IN A \\ SCOTTISH FIRE FESTIVAL
}

\author{
THOMAS A. MCKEAN
}

This paper looks at a Scottish fire festival, the "burning of the Clavie" at Burghead in the North East of Scotland, and its practitioners in relation to external authorities, particularly the police and regional political administrators. Internal and external pressures for change and stability are examined and author explores the negotiation between insiders and outsiders that co-create the ritual as it is practiced today. Keywords: Tradition, Negotiation, Calendar Custom, Creativity, Stability.
V razpravi avtor najprej tematizira škotski praznik, "kres Clavie" v Burgheadu na severovzhodu Škotske, izvajalce in njihovo razmerje z oblastmi, posebej policijo in regionalno politicno upravo; nato obravnava notranje in zunanje pritiske, ki vplivajo na obranjanje ali spreminjanje rituala, ter raziskuje pogajanja med notranjimi in zunanjimi akterji, ki so-ustvarjajo današnjo podobo rituala.

Ključne besede: tradicija, pogajanje, koledarski ritual, kreativnost, stabilnost.

This paper looks at a Scottish fire festival, the "burning of the Clavie" at Burghead in the North East of Scotland, and its practitioners in relation to external authorities, particularly the police and regional political administrators. Cultural tradition, as Regina Bendix says, does not exist, it is made (2009: 255). In fact, it is constantly remade, with change being a crucial part of reiterated practice. I use the phrase "evolving fidelity" to describe the idea that preserving a tradition, through enacting it, often involves changes designed to retain or improve an event's "traditionality". This change comes from several sources, from within and from outside, and it is usually conceived of in relation to a notion of stability - tradition - which derives from the accepted way that things are done, and are perceived to have been done, for (sometimes imagined) centuries.

Burghead lies on the north coast of the cold shoulder of Scotland, around seventy kilometers east of Inverness. Each January 11 - Aul Eel (Old Yule), New Year in the Julian calendar ${ }^{1}-\mathrm{a}$ half barrel filled with burning staves and creosote is carried by a team of men - the $\mathrm{Crew}^{2}$ - on a fixed route around the village before being immolated, in showers of diesel and creosote, atop the ancient Pictish fortification at the top of the town. The ritual is a longstanding one, with written evidence as far back as the seventeenth century, but with a local oral narrative that takes it much further back; several Burghead locals

1 While a papal bull decreed the ten-day shift to the Gregorian calendar in 1582, this was not adopted in Great Britain until 1752 (McNeill 1957, III: 15), by which time it was necessary to shift by eleven days. Hence, the burning of the Clavie takes place on 11 January.

2 I am defining this community - the Crew - using their own criteria, neatly sidestepping Dorothy Noyes's caution as to who has the right to decide who the "authentic guardians" of a tradition are (Noyes 2006: 28, 32). 


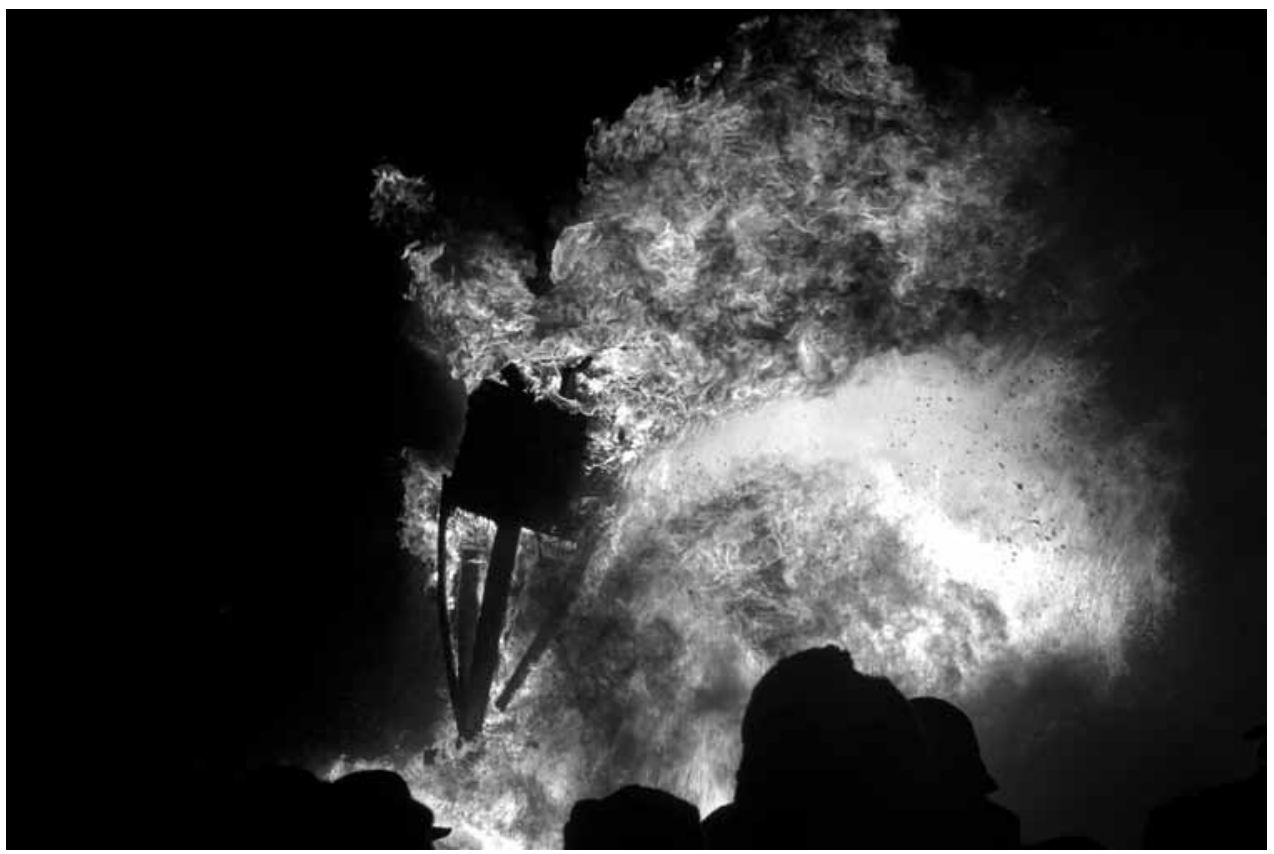

Figure 1. The Clavie in flames at the top of Doorie Hill, 2011. (Photo: T.A. McKean)

have cited Pictish or Roman origins. ${ }^{3}$ The first written evidence, from the Records of the Presbytery of Elgin, 11 January 1655, describes the use of fir torches, rather than a barrel and the word "clavie" is not used (Banks 1939, II: 35). It is frequently mentioned in the Kirk-Session records of nearby villages Drainie and Duffus (cited Banks 1939, II: 35), but custom was not exclusively coastal and many other villages in Scotland also used to have similar events, featuring burning barrels, boats, torches and bonfires (McNeill 1957, III: 100). Throughout these records, the practice is referred to as "old" and later writers on customs regularly cite these seventeenth and eighteenth century sources (e.g., Chambers 1869; McPherson 1929). Today, the Clavie is one of a number of fire festivals found around the British Isles, from Shetland's Up-Helly-Aa at the end of January to the shoulder-borne burning barrels of Ottery St Mary in Devon in the south of England.

Over the years, some of the fine points of the Clavie's practice have evolved as it has adapted to contemporary needs, capabilities and circumstances, but beneath these adaptations and changes lies a deep community loyalty to tradition, continuity and stasis. It is important to its practitioners and participants that the Clavie as an ancient custom and is seen as such. This lends it cultural capital, helping to protect it against incursion and dilution.

3 Information from Burghead residents derives from more than twenty years of conversation in the community. Later quotations from Dan, Danny and Lachie Ralph are drawn from interviews recorded for the Elphinstone Institute, University of Aberdeen, cited in the reading list as Dan Ralph 1998 and Lachie Ralph 1998. 
Dan Ralph, the current Clavie King, leader of the Clavie Crew, connects Burghead's history with a powerful Pictish settlement of more than a thousand years ago, and with a later Viking community. The Clavie's stopping point at the end of its procession through the town is on Doorie Hill, inside the ramparts of the ancient fort. Dan's son, Danny, also a prominent member of the Crew, is a stone carver who draws upon Pictish and Celtic symbols and art for his work, linking his current practice to the area's cultural past. Visitors are often shown to the village's ancient well, carved out of the rock at the upper end of the village, near the remains of the Pictish fortress. In its present form, the well probably dates to the Dark Ages, but the carved steps and cistern may have been used by the Picts; it is also, sometimes, said to be Roman). The lighting of the Clavie is performed from the "aul manse dyke", the wall of the historic home of Provost Jeffries, the same place each year; the route around the village taken by the Clavie Crew is always the same (noted in the Edinburgh Evening Dispatch), and has been as long as anyone can remember. The Clavie stops at "certain houses" and "certain street-corners" (Evening Dispatch; cited Banks II, 32) to deliver a burning or burnt stave for luck.

I cite these narratives not for their individual content, but for their nature: they are about continuity, the deep rootedness of the tradition in the area's historic past. The Crew members look to their oral legacy, of which they have a wide-ranging knowledge, and which has been of great benefit to academic and journalistic researchers over the years. But they also actively reach beyond this resource, to historians, books and archives, to Dan Ralph's extensive collection of ephemera related to the Clavie, and to connections with academics such as Emily Lyle, Margaret Bennett, me, and local man, the late Ian Shepherd, who became the regional council's archeologist. Danny Ralph has written up a narrative of the Clavie's history and origins, both out of his own interest and as a response to outsiders asking questions.

Community is as important as history in anchoring the Clavie custom in traditionality. Simply put, to be a member of the Crew you must be born in Burghead.

They're greatly the envy of their peers, who would like tae be part [of it], but they've no real connection an they've got tae stand an watch, [...] But it can't be a free for all; it must be kept for real Brochers. ${ }^{4}$ [...] If ye didn't observe this, ye wid have ousiders creepin in. [...] Not that we have anything against ootsiders, but we don't want tae dilute the tradition in any way. Keep it fairly pure. (Dan Ralph)

The born-in-Burghead criterion is used as a means of keeping the Crew relatively homogeneous and the practice within the control of locals (but compare the Berga fire festival in Spain, where officials have begun awarding points for, among other things, being born in the town, which is seen by some as divisive and contrary to the festival's historically integrating nature; Noyes 2006: 40). Carrying the Clavie, as a member of the Crew, is a

4 Burghead's local name is the "Broch", based on the common pronunciation of the "burgh" element;

Fraserburgh, $110 \mathrm{~km}$ to the East has the same byename, for the same reason. 


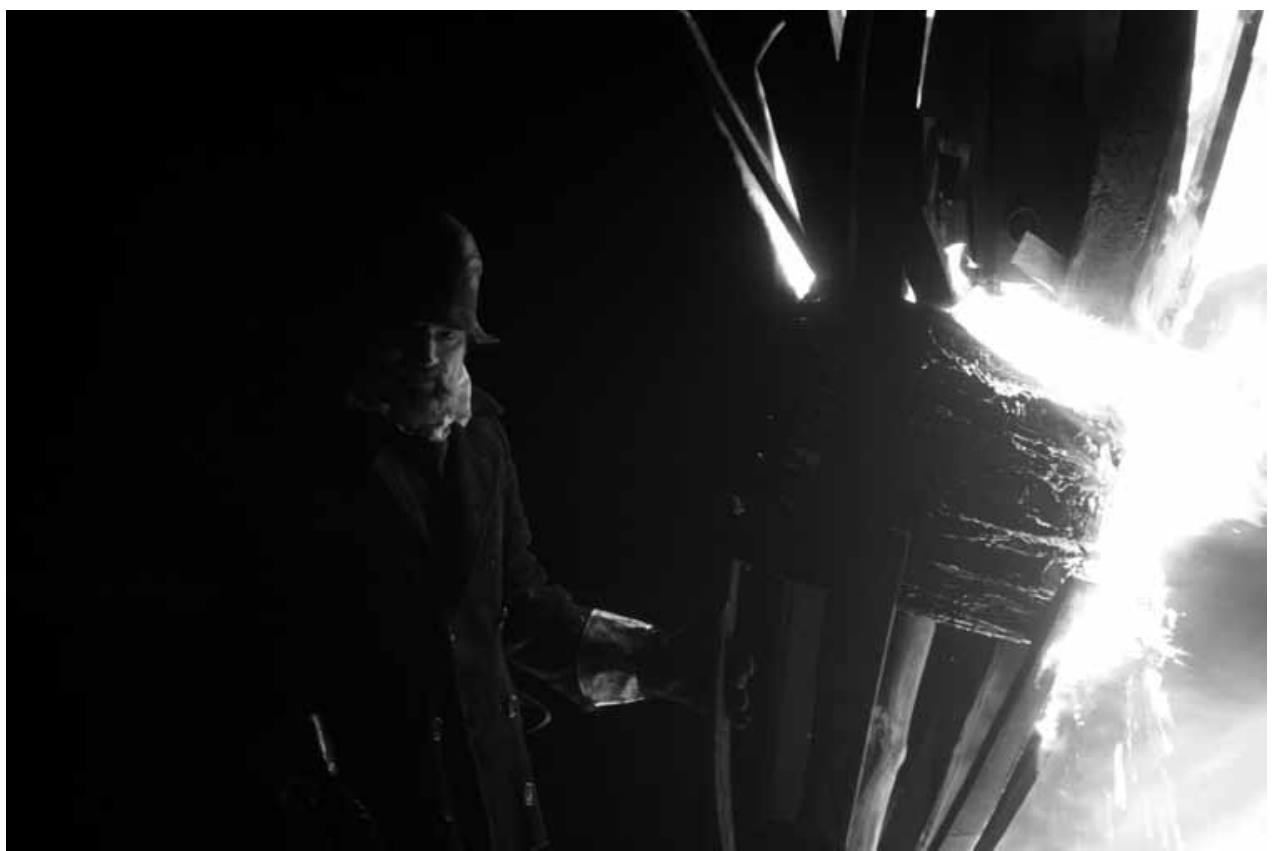

Figure 2. Dan Ralph refueling the Clavie, 2011. (Photo: T.A. McKean)

lifetime's privilege and duty. "There must come a time in every Crewmember's life when he has tae stop carryin," says Dan. "I dread that happenin."

The Crew take their cultural stewardship of the event seriously. The kingship of the Crew is passed down in families, unless there is no successor, in which case the king is voted in from among the Crew. Dan maintains that he was elected because he could keep a cool head at the burning itself, but his choice of words is telling:

I try tae keep a cool head all the time, a clear head tee. That could be the reason, bit I think really they know that I'm a stickler for tradition, steeped in tradition. They knew I wouldn't allow it tae alter in any way, or be modernized. [...] It's got tae be tradition an nothing else. It's so important. Important not jist tae Burghead, it's important tae the whole of Scotland and all ower the world, really, that these traditions are kept alive and unchanged.

It's of great importance tae be involved in, tae make an attempt tae keep it traditional.

This sense of traditionality extends, of course, to the making of the Clavie itself. "Unwritten but unvarying laws regulate all their actions", according to a report in the Edinburgh Evening Dispatch of 16 January 1889 (Banks 1939, II: 32), unwritten, but well-understood rules. The upright stake used to support the Clavie is a "salmon post", so called because it used to come from the local salmon fishermen, who used them to stake out their coastal 
nets. There have been no (legal) salmon fishermen in Burghead for many years, but the post is still referred to as a "salmon post". The large, hand-wrought nail used to attach the Clavie to the post is the same one each year. The "hammer" used to knock the nail in is said to be a "Pictish throwing stone". "The Clavie wis always built right next tae the hoose here," notes Dan, "on the salmon green" (which is no longer there).

Clearly from these narratives, and the choice of words, the idea of history, the idea of connectedness, is just about as important as any actual historical continuity. The nail, for example, was actually always a new one until the village blacksmith died in the 1930s and there was no one to make one. Thus, a new accretion of tradition and continuity has quickly grown up around the reused nail.

With membership of the Crew comes a great responsibility, not just for the event's traditionality, but for the safety of the carriers, the general public and property along the route. For example, the Clavie used to be carried across the fishing boats gathered in the harbour, and each blessed with a charred splinter, but according local history, a boat was set on fire over a century ago and the practice discontinued. Dan, as King, is always greatly relieved when the Clavie - carried full of burning and boiling tar - is safely finished, with no accidents, but, in fact, responsibility lies with the entire Crew. Lachie Ralph, Dan's son, reflects on his likely succession in this light:

In a way I don't want tae [be Clavie King], cause everybody thinks ye're in charge of it, ifye know what I mean, but in actual fact, it's the whole Crew.

So, the whole Crew bears responsibility for the safe enactment, a fact which is key in relation to pressure brought in recent years by the police authorities and the regional council, concerned over public safety.

No traditional practice is static; indeed, though change is often not volitional, customs evolve in order to retain vitality and relevance, usually in a fairly conservative way, but they alter nevertheless. For the Clavie, change is mostly due to simple variation over time, but it can also come from within the Crew itself. Some Crewmembers wear fireproof gloves, for example, and coal-tar-derived creosote took the place of pine-based "Stockholm" tar for the final hilltop conflagration some years ago. Even before 2003, when the sale of coal-tar creosote was made been illegal in Britain (Health and Safety Executive 2012), the Crew was already using diesel as a fuel. It burns hotter and has damaged the stone altar atop the hill, but its use continues. So while they are "stickler[s] for tradition", they also feel a responsibility to the community and to the onlookers. "We don't want tae reduce the spectacle, either," says Dan. One fundamental change - the makeup of the Crew - is due to the fact that few if any children are actually born in Burghead. There is no village hospital and there are few home births. Eligibility for the Clavie Crew is therefore - matterof-factly - extended to those born of Burghead parents in the City and Royal Burgh of Elgin, $13 \mathrm{~km}$ away, a town of some 90,000 inhabitants.

5 See Chambers 1869, "December 31st", for a full description of the Clavie's construction, little changed from that narrated in 1998 by Dan and Lachie Ralph (Bold and McKean 1999). 
Perhaps the most obvious change in recent decades has been in the barrel itself. An extensive nineteenth-century article in the Banffshire Journal (Chambers 1869), reports on the making of the Clavie, and calls for an Archangel tar barrel, a wooden cask, bound with wooden hoops historically used to ship pine tar from the White Sea port of Arkhangelsk. Of course, even the Archangel tar barrel must have been an innovation at one time. Pine tar has been used for centuries in maritime contexts and the highest grade came to be called "Stockholm", or "Archangel" tar after the Norrländska Tjärkompaniet (the Wood Tar Company of North Sweden) was granted sole export privileges by the King of Sweden in 1648 (Kaye 1997). The Archangel barrel itself would have evolved, so the form used by Brochers is fairly recent in historical terms. Previously, different types of barrel were probably used, or perhaps even an entirely different container. The point is that the Archangel tar barrel is seen to be the correct type by the Crew and community. It is the type used before, and within living memory. Its introduction extends back to before living memory, which makes it ancient, primary, and therefore correct.

The last Archangel tar barrel was burned in the 1950s:

We, as children, drove everywhere looking for an Archangel tar barrel, remembers Dan.

We got the last one aroond fifty year ago, at Findhorn, where they used it for the salmon fishin trade. Bit that wis the last one. I can remember, [...] I wis perhaps fifteen or sixteen an too young tae make any comment. We'd been asked at the time tae provide a replica Clavie for a museum in Edinburgh an I thought tae maself, since this is the last Archangel tar barrel, this has got tae be the one that'll go tae the museum. I stood back while they made two Clavies an someone said, "Which ane's goin tae the museum?" An ma father said, "The whisky barrel, cause the Clavie's mair important than any museum," he said. So sadly they burned the last genuine Archangel barrel.

The Brochers had no option but to alter the tradition, not its practice, but its materiel. There have been other such points of forced evolution: In the 1930s, young people carried small Clavies around the town, bringing them to the center where they threw them together to create a large bonfire. The blackouts during World War II put paid to such large-scale fires and even the carrying of the full size Clavie for a time (Neilly and Shepherd 1992: 91).

After the last tar barrel was used, a heavy oak whisky barrel served for many decades, but about ten years ago, Dan, a joiner by trade, took it upon himself to reintroduce the Archangel barrel.

We had nothing tae refer to, except a few old photographs. We had tae judge the scale according tae who wis standing beside it in the photo an he wis only five feet three. [...] We've got the scale jist aboot right. It wis good fun anyway. An it wis great tae get the sceptics going.

This kind of deliberate innovation adds a layer of complication. The conscious attempt to re-create past forms which are perceived as having authority is a testament to the Crew's need to have the event anchored in the pre-remembered past. It is a "way of synchronizing 
the heritage clock with the historical clock" (Kirschenblatt-Gimblett 2004: 60), though it comes from within a living tradition, rather than being imposed from outside by a "heritage" organization. Such direct connections to origins give the event the aura conferred by authenticity, even if that authenticity is a (re)created one. So, in this instance, the best way to maintain the tradition was, ironically, to change it, albeit towards a past that, in the Crew's eyes, has been stable over a several hundred year period, well beyond living memory. This medium-term stability is, in effect, what we mean by "tradition".

There are also pressures for change within the wider community itself. The Church's relationship with the Clavie over the centuries, for example, while too involved to go into here, has varied from condemnation in the Kirk Session records of 1704 as a Pagan ritual - "a great and gross scandal and Idolatrous custome" (quoted Banks 1939, II: 36) - to the current minister's embracing of it as a community event; he even offers a "Clavie service" on the Sunday nearest January 11. In acquiring a stake in the ritual, the Church gains the approbation of those who take part, but also basks in the event's reflected glory, a kind of partial co-option the Church has been using to absorb and control non-Christian practices for centuries. ${ }^{6}$

Another example of internal community pressure came in the 1890s, when the so-called "New Stylers" wanted to move the event to December 31, New Year in the newfangled Gregorian calendar, which only came to Britain in 1752. An extract from a local poem of the time sums up the conflict:

\begin{tabular}{|c|c|}
\hline They tried fu' hard to change the nicht, & ] full; night \\
\hline But losh! it wis an awfu' sicht, & ] Lord; awful sight \\
\hline The natives ran wi' a' their micht & J might \\
\hline New "stylers" ran in such a plicht, & / plight \\
\hline Man, didn't they snarl.? & \\
\hline
\end{tabular}

Dan notes, "They were unsuccessful, which is great because I think along wi the Shetland isle o Foula, we're the only ones celebrating anything on Aul Eel, the 11th o January." It is important to Brochers - and to many other practitioners of tradition - to be exceptional, to be different, different from other communities round about (for example through blason populaire with neighbouring Hopeman, in Burghead's case), but also to demonstrate their sense of belonging and rootedness, their ur-Scottishness. ${ }^{8}$ Uniqueness is part of the Clavie's appeal, then, but it is also a protection in modern times, and a selling point in relation to the authorities, as we shall see.

6 In a fairly recent example, Edinburgh's Beltane/May Day dawn ritual of face washing in the morning dew on Arthur's Seat now features a church minister who blesses the event and its participants. Such Christianization phenomena are complex, however and in the case of holy wells, for instance, the mediaeval church practically created their associated cults, albeit drawing on pre-Christian traditions (Rattue 2001 66).

7 Courtesy of Dan Ralph collection.

8 I take on board Dorothy Noyes's caution against casual ethnocentricity and "presentism" (2006: 33) and view traditional practices as being about drawing outside attention to a community as well as defining identity and exclusivity. 
One internal pressure, notable by its absence, is the notion that women could take part in the making or carrying of the Clavie. This is never really spoken about and appears, simply, not to be on the agenda. "It's traditional, in a way, for it jist tae be men. [...] Aye it's jist a all man thing. The women do the cookin for the cèilidh afterwards, bit that's as far as it goes" (Lachie Ralph). The fact that the Crew is all male is mentioned, but I have hardly ever heard any woman, even the King's own daughters, say that they would like to carry it. Outsiders frequently say that they would like to carry it, but the non-inclusion of women seems to be broadly accepted. Women have a part to play in their traditional roles of providing hospitality before and after the event, and nowadays also as marshals during the Clavie's procession around the village.

Thus far, the "rules" and practices discussed have come from within the village and the Crew itself. But there are also exoteric factors that influence, drive, or steer the event, leading to tensions between modernizers and "traditionizers", and between the internal and the external. "We've had a wee bit of crowd control forced upon us by the authorities", notes Dan, reflecting the growing pressure towards regulation and containment from the police and local government, who see the practice as too dangerous and unpredictable for the UK's safety-conscious, litigious world. In a post UNESCO environment, Barbara KirshenblattGimblett notes, the authorities are "supposed to promote awareness, dialogue, and respect through such valorizing devices", such as their list of Intangible Cultural Heritage (55). Burghead's local authorities, coming from a local perspective, are less invested in this big picture and more concerned with their remit for public safety.

Over the past ten years, the changes requested have varied from adding a number of marshals in high-visibility jackets walking just outside the circle of Crewmembers (usually Crew wives), keeping the crowd back one more layer, ambulance staff walking with the Crew, a fire engine atop Doorie Hill and barriers around the hill to prevent the crowds getting too close, or having the burning barrel rolling down the hill into them at the end of its life.

"All heritage interventions - like the globalizing pressures they are trying to counteract - change the relationship of people to what they do," writes Barbara Kirschenblatt-Gimblett (2004: 58) and the political interventions related to the Clavie, though framed in terms of public safety rather than the preservation of tradition, are no different. The Crew meets several times a year - designing their heritage anew - in preparation for the next Clavie and, over the last decade, these meetings have largely been taken up with addressing these outside pressures for change. In annual negotiations with the authorities, the Crew tries to retain control of the shaping of the event, ensuring that its character is preserved. In doing this, they rely on insider knowledge - "the (mental) competence of those who have traditionalised the practice" in the first place, in Bendix's terms (2009: 263) - the idea, as Lachie Ralph noted, that they know more about how the thing burns, how the crowds move and how to protect themselves, other people, and the built environment, than any other group. Not only do the Crew naturally act as a kind of marshalling team themselves, urging the crowd back when the Clavie turns or is on the move, but the Crew wives form 
another informal layer, whether uniformed or not, and they, in turn, are surrounded by community members who also know how it works. There is, in effect, a multi-level shield wall around the Clavie itself.

The police and the council, of course, have absolute power here and could shut the event down completely, if they chose to do so. It is to their credit that they have negotiated each season and that they have not become entrenched in a single, fixed position, or routinely increased regulation year upon year. Such flexibility means, however, that each and every year there is a serious and high-stakes negotiation as to whether the event will happen and in what form. Other UK fire festivals have faced similar issues, of course. In Ottery St Mary, for example, the Daily Telegraph reported in 2010 that the "Centuries-old Ottery tar barrel race [is] at risk after insurance rose 1150 per cent." So far, compromises have been reached and the event has, broadly speaking, gone ahead as the Crew would have wished.

Outside authority has a positive face, too, and Dan has also called upon it in support. In 2007, I was asked to write a letter addressed to the regional police authority, on the basis that academic endorsement of the cultural importance of the event to the community and the region would be of some use in resisting pressure, particularly in terms of public safety versus the shape of the event. Thus, the Crew was able to draw on the external authority of a university and, by extension, UNESCO's Recommendation on the Safeguarding of Traditional Culture (UNESCO 2003), which I cited in the letter, to underscore their natural, emic cultural convictions. Though secure in their own knowledge, the Crew was not afraid to reach for an appraisal that they knew would play as "high status" to the police.

Over and above the pressure from the authorities, there is huge outside influence from the media and from tourism promoters. The event has seen as many as four professional camera crews, including one from Japan. These can become a bit much, especially when directors ask for second takes. Some concessions are made, during the building of the Clavie, which is a very much more controlled and controllable setting than the burning, but not elsewhere. In general, the Crew response is,

Ye'll have tae take us as ye find us an we'll do our own thing. I've got mixed feelins aboot the media. It's fine, but ye'd have tae watch an not let them dominate.

There is an influx of people from Scotland and around the world - a weekend Clavie can draw around 3000 people, a weekday one usually fewer. The local and national newspapers also cover it and despite locals' ambivalence, one of the Crew's first jobs the day after is to get the newspapers, with an eye to assessing the coverage and the crowd's satisfaction.

The natural follow-on from all this attention is, of course, actual marketing of the event as a tourist destination by local organizations, authorities, and enthusiasts. It appears on numerous websites both from an informational perspective (like Wikipedia) and a promotional one, like Burghead's own Headland Trust (which, oddly, labels it a "bizarre" fire ritual), or welcometoscotland.com: "Ancient traditions are rekindled at this ancient 
fire festival." The event even has its own facebook page, BurningOfTheClavie. Curiously, though, the "This is Moray" information portal, while featuring an extensive page on Burghead and its history, makes no mention of the Clavie whatsoever.

The Clavie has clearly made the transition from "accumulated communal experiences" to commodified heritage, in Robert Peckham's formulation (cited Bendix 2009: 253), but has not reached the stage of being a "mode of cultural production that gives the endangered or outmoded a second life as an exhibition of itself" (Kirschenblatt-Gimblett 2004: 57, italics mine). It is thus still a living cultural expression, in no danger of dying out through community neglect. As such, it has no need of UNESCO Intangible Cultural Heritage listing, which despite its positive intent still derives from a preservation paradigm predicated on fragility. While the Clavie is vulnerable is to periodic pressure from outside authorities, the participants pretty much exist in their own world. Outsiders are welcome, but they are not particularly acknowledged. To Lachie Ralph, the crowd is all a blank, really. Jist the Crew an the Clavie. Everythin else is forgotten about. Ye're all there, ye're all helpin one another. It's somethin else, like. Families are carryin it, rather than jist Brochers themselves.

Dan Ralph adds,

A doctor friend, who'd seen the Clavie for the first time, said tae ma wife,

"I've certified people for doin less than that!" [...] That sort o sums it up!

They think we're primitive here, [laughs] but I think that's what we really want them to think. [laughs]

Again, a sense of the extra-ordinary is used as an enfolding protective device. Nevertheless, the numbers attending, the media profile, and the event's potential as a tourist destination immeasurably strengthens the Crew's case that the Clavie be allowed to continue in its present form. These internal and external pressures, and the community's and Crew's resistance to them, show that the basic understanding of the practice as held by the two groups - the Crew and the authorities - is quite different.

- The Crew sees the Clavie as a cultural practice, part of the fabric of community life, something that has "always" been done, a part of the natural environment, almost not worthy of remark;

- The police and council see the Clavie as a public event, and therefore part of a longstanding public event paradigm, complete with its assumptions of the need for structure, controls, regulation, external authority, and formal (recorded) planning steps (see, for example, the Burghead and Cummingston Community Council minutes for 3 November 2011; BCCC 2011).

These two paradigms, coming as they do from almost opposite perspectives, are bound to conflict. The Crew does not recognize the police's authority to control, alter or affect the practice, or even the need for them to do so. They are well aware, too, that the police do not fully accept the extensive emic knowledge, control, practice and safety structures that the community has built up over many years' experience. 
Such internal and external forces for continuity and change allow us to see the direct tensions between, say, Crew-directed safety monitoring and the authority's introduction of barriers and a police presence.

\section{Internal Forces}

Continuity

Crew-annual practice

Change

Crew - monitoring safety

Crew - making more traditional

Crew-dealing with media

\section{External Forces}

Continuity Media/University/UNESCO - valorization

Change

Authority - safety planning, policing

Authority - contain, regulate, regiment

Authorities, enthusiasts - marketing, publicity

Likewise, the impulses towards containment, stasis and expansion come from various sources:

\section{Containment}

Council

Police

Insurance needs

Church (formerly)

New Stylers

\section{Stasis}

Crew

Academics

Change, whether from inside or out, is thus both enemy and friend to "authenticity" and "traditionality" and is both to be welcomed and resisted.

\section{Continuity}

Internal

Ensure event's stability and perpetuation

External $\frac{\text { to be welcomed }}{\text { Valorizing academic study and tour- }}$ ism, for example, can be seen as reinforcing the event's cultural capital, but can suppress the natural organic change and adaptation necessary for the event's long-term survival.

to be welcomed / resisted

\section{Expansion}

Community support

Media attention (TV, news, web)

Academic publication

Tourism

\section{Change}

Anchor current practice more firmly in the past, but New Stylers wanting to change date reduces exceptionalism

Undermine continuity, stability, and the Clavie's internal regulatory mechanisms and practices.

to be resisted 
Together, these perspectives outline a modern, flexible and creative concept of what we mean by "tradition" and show the influences that impact upon it.

Positive:

Ambivalent (shaded):

Negative (hatched): internal continuity

internal change / external continuity

external change

In fact, these different kinds of pressure co-create the ritual as it is practiced today. I think we may assume that - while the players and the particular content of their aspirations differ - a very similar process has been going on for much of the Clavie's life. In former times, it was the Church which aspired to eradicate it, on moral and religious grounds. In opposition, early practitioners would undoubtedly have looked back to their own "more authentic" times, just outside the reach of remembered history, looking for continuities and links to their ancestors' sense of tradition and, ultimately, to the authority of the past. Today's situation, therefore, is perhaps little different from any time in the Clavie's 400 year (or more) history. While each performance is intangible and evanescent, the tradition is not disappearing. The struggle between modernizers and traditionizers, between external and internal influences, between change and continuity, between past history and the future to come, in fact encapsulates the process of tradition as it really works - constantly evolving its fidelity to an idea of stable tradition. The tensions, friction and energy between these multiple binaries yield the energy and ownership that ensures true cultural continuity.

\section{REFERENCES}

Banks, Mary Macleod

1939 British Calendar Customs, Scotland. Volume II: The Seasons, the Quarters, Hogmanay, January to May. For the Folklore Society. London: William Glaisher; Glasgow: John Wylie.

BCCC (Burghead and Cummingston Community Council)

20113 November 2011 (http://www.moray.gov.uk/downloads/file77556.pdf; accessed 7 March 2012).

Bendix, Regina

2009 Heritage between Economy and Politics: An Assessment from the Perspective of Cultural Anthropology. In: Smith, Laurajane and Natsuko Akagawa (eds.), Intangible Heritage. Key Issues in Cultural Heritage. London: Routledge, 253-269.

Bold, Valentina and Thomas A. McKean

1999 Northern Folk: Living Traditions of North East Scotland.CD-ROM. Aberdeen: Elphinstone Institute.

Burning Of The Clavie

2012 Burning Of The Clavie (http://www.facebook.com/BurningOfTheClavie; accessed 13 March 2012).

Chambers, Robert

1869 The Book of Days: A Miscellany of Popular Antiques in Connection with the Calendar including Anecdote, Biography and History, Curios<ities of Literature, and Oddities of Human Life and Character. London and Edinburgh: W \& R Chambers. (http://www.thebookofdays.com/; accessed 1 March 2012). 
Daily Telegraph

2010 Centuries-old Ottery tar barrel race at risk after insurance rose 1150 per cent. Daily Telegraph, 6 November 2010.

Headland Trust

2012 Burghead Headland Trust (http://website.lineone.net/ cathm19/; accessed 22 March 2012).

Health and Safety Executive, UK Government

2012 Regulatory Action and Decision Archive (http://www.hse.gov.uk/biocides/regulatoryarchive.htm; accessed 5 March 2012).

Kaye, Theodore P.

1997 Pine Tar; History And Uses (http://www.maritime.org/conf/conf-kaye-tar.htm; accessed 7 March 2012).

Kirk Session Records

1704 Kirk Session Records, Parish of Inveravon, 16 August 1704. National Archives of Scotland, $\mathrm{CH} 2 / 191 / 2$.

Kirschenblatt-Gimblett, Barbara

2004 Intangible Heritage as Metacultural Production. Museum International 221-222 (Vol. 56, No. 1-2 (2004): 52-65.

McNeill, F. Marian

1957 The Silver Bough: A Four Volume Study of the National and Local Festivals of Scotland. Glasgow: William MacLellan.

McPherson, J. M.

1929 Primitive Beliefs in the North-East of Scotland. London: Longmans, Green.

Neilly, Marne, and Nan Shepherd

1992 Burning the Clavie at Burghead. Tocher 44: 91-103.

Noyes, Dorothy

2006 The Judgement of Solomon: Global Protections for Tradition and the Problem of Community Ownership. Cultural Analysis 5 (2006): 27-56.

Ralph, Dan

1998 Interview with Dan Ralph, 15 June 1998, by Thomas A. McKean and Valentina Bold. Elphinstone Institute Archives, University of Aberdeen. EI BV 1998.024.

Ralph, Lachie

1998 Interview with Lachie Ralph, 15 June 1998, by Thomas A. McKean and Valentina Bold. Elphinstone Institute Archives, University of Aberdeen. EI BV 1998.025.

Rattue, James

2001 The Living Stream: Holy Wells in Historical Context. Woodbridge: Boydell.

This is Moray

2012 This is Moray (http://www.thisismoray.com/burghead-in-moray-c149.html; accessed 22 March 2012).

UNESCO

2003 Text of the Convention for the Safeguarding of Intangible Cultural Heritage. General Conference of the United Nations Educational, Scientific and Cultural Organization, thirty-second session, Paris, 29 September-17 October, adopted 17 October (http://www.unesco.org/culture/ich/index. php?lg=en\&pg=00006; accessed 5 March 2012).

Welcome to Scotland

2012 Welcome to Scotland (http://www.welcometoscotland.com/things-to-do/events/aberdeen-grampian/burning-of-the-clavie; accessed 22 March 2012). 


\section{UPRAVLJANJE IN VZPOSTAVLJANJE ZVESTOBE V ŠKOTSKEM PRAZNIKU} CLAVIE

Članek obravnava ritualni zažig soda oz. Clavieja, kakor mu pravijo v Burgheadu v severovzhodni Škotski. Gre za novoletni festival, ki se vsako leto odvija 11. januarja, torej še po julijanskem koledarju. Clavie je polovica soda, pritrjenega na debel drog, ki ga prižgejo, podkurijo z dogami in kreozotom ter nosijo naokrog po ulicah po ustaljeni poti. Najstarejši ohranjeni zapisi so iz sedemnajstega stoletja, sam ritual pa naj bi bil starejši, morda še iz rimskih časov. V ritualu zažiganja soda labko sodelujejo le tisti, ki so rojeni v Burgheadu ali v bližnjem Elginu.

Avtor analizira povezave izvajalcev z oblastmi, posebej s policijo, pa tudi z lokalno in regionalno politično administracijo. Ritual zažiga soda je javni dogodek. Tradicija in kontinuiteta sta za skupnost ključnega pomena in ekipa, ki nosi in zažge sod, jemlje svojo službo zelo resno; a kljub temu se je ritual razvil in se tudi prilagodil sodobnim potrebam. Sodelujoči so uvedli stevilne spremembe, npr. nove materiale; zaradi zunanjih pritiskov so okrepili in poostrili varnostne ukrepe. Izvajalci in zunanji akterji vplivajo tako na spreminjanje kot na ohranjanje ritualne prakse. Avtor na kratko predstavi tudi vplive globalizacije, različnih režimov zaščite dedišćine in izvedbe rituala primerja z angleškimi praksami. Današnjo podobo rituala soustvarjajo avtentičnost, tradicionalnost in zvestoba na eni in spremembe in menjave na drugi strani.

Prof. dr. Tom Mc Kean, University of Aberdeen, The Elphinstone Institute, MacRobert Building, King's College, Aberdeen, AB24 5UA, t.a.mckean@abdn.ac.uk 